\title{
Vascular Plant Diversity as a Surrogate for Bryophyte and Lichen Diversity
}

\author{
EMMA J. PHARO,${ }^{*} \ddagger$ ANDREW J. BEATTIE, ${ }^{*}$ AND DOUG BINNS $\dagger$ \\ *School of Biological Sciences, Macquarie University, New South Wales 2109, Australia \\ †Ecology Section, Research Division, State Forests of New South Wales, 27 Oratava Road, West Pennant Hills, \\ New South Wales 2125, Australia
}

\begin{abstract}
An important issue in conservation biology is the extent to which one group of organisms can function as a surrogate for less well-known groups. We explored the extent to which vascular plant species diversity (both $\alpha$-diversity, or species richness, and $\beta$-diversity, or turnover) and the subgroups of understory, overstory, and ferns can act as surrogates for bryophyte and lichen species diversity. We surveyed 35 sites in a range of forest types in the coastal lowlands of eastern Australia. Fern species richness was strongly positively correlated with bryophyte species richness but negatively correlated with lichen species richness. Fern, bryophyte, and lichen species richness all varied significantly with time since fire, vascular plant cover, and topographic position gradients. Of the other vascular plant groups, the only significant correlation was between overstory and bryophyte species richness. We quantified species turnover using modifications of Whittaker's original measure as well as multivariate techniques. The rate of lichen species turnover was the lowest of all six groups investigated. The other five groups had similar rates of species turnover, although the results were different depending on the emphasis of the measure used. There were significant correlations between the patterns of species turnover of bryophytes and lichens and those of all four vascular plant groups, but none of the correlations was particularly strong. The understory and all vascular plants were the best predictors of the species turnover pattern of bryophytes and lichens, and correlations appeared strongest in wet sclerophyll sites. With respect to management practices, time since the last fire appears to be an important determinant of bryophyte, lichen, and vascular plant diversity, and logging appears to differentially affect the diversity of the different plant categories. A mosaic of logging and fire intervals and intensities appears to be important for maintaining regional diversity.
\end{abstract}

Diversidad de Plantas Vasculares como Substituto de la Diversidad de Briofitas y Líquenes

Resumen: Un asunto importante en biología de la conservación es la magnitud con la cual un grupo de organismos puede funcionar como substituto de grupos menos conocidos. Exploramos la magnitud a la cual la diversidad de plantas vasculares (tanto diversidad $\alpha$ o riqueza de especies y diversidad $\beta$ o revovación) y los subgrupos sotobosque, dosel y belechos pueden actuar como substitutos de la diversidad de especies de briofitas y líquenes. Muestreamos 35 sitios en un rango de tipos de bosque en las tierras bajas de la costa Este de Australia. La riqueza de especies de belechos estuvo fuerte y positivamente correlacionada con la riqueza de especies de briofitas, pero negativamente correlacionada con la riqueza de especies de líquenes. La riqueza de especies de helechos, briofitas y líquenes varió signifcantivamente a lo largo del tiempo en gradientes de incendio, cobertura de plantas vasculares y posición topográfica. De los otros grupos de plantas vasculares, la única correlación signifcativa fue entre la riqueza de especies del dosel y las briofitas. La renovación de especies se cuantificó usado modificaciones de las medidas originales de Whittaker, así como técnicas multivariadas. La tasa de renovación de líquenes fue la mas baja de los seis grupos investigados. Los otros cinco grupos tuvieron tasas similares de renovación de especies, aunque los resultados fueron diferentes dependiendo del énfasis de la medida usada. Hubo diferencia significativa entre los patrones de renovación de especies de briofitas y líquenes y aquellos de los cuatro grupos de plantas vasculares. Sin embargo, ninguna de las correla-

‡Current address: Sustainable Forest Management NCE, G-208 Biological Sciences, University of Alberta, Edmonton T6G 2E9, Alberta, Canada, email emma.pharo@ualberta.ca

Paper submitted March 18, 1998; revised manuscript accepted August 14, 1998.

282

Conservation Biology, Pages 282-292

Volume 13, No. 2, April 1999 
ciones fue particularmente fuerte. Las plantas del sotobosque y todas las plantas vasculares fueron los mejores pronosticadores de los patrones de renovación de especies de briofitas y líquenes y las correlaciones aparentemente fueron fuertes en sitios mojados de esclerófila. Con respecto a las prácticas de manejo, el tiempo desde el último incendio aparenta ser un factor determinante para la diversidad de briofitas, líquenes y plantas vasculares. La tala parece afectar diferencialmente la diversidad de diferentes categorías de plantas. Un mosaico de intervalos e intensidades de incendios y talas parece ser un factor importante para el mantenimiento de la diversidad regional.

\section{Introduction}

Whether or not organisms with well-known taxonomies can function as surrogates for less well-known organisms is an important question in conservation biology (Noss 1990; Tracy \& Brussard 1994; Faith \& Walker 1996). There are never the resources or expertise necessary to survey the total biodiversity of an area; as a result, taxonomically difficult groups such as bryophytes and lichens are rarely included, despite being diverse (Resource Assessment Commission 1993; Stolgren et al. 1995). When they are sampled, they are often lumped in with vascular plants. Bryophytes and lichens, however, may have very different patterns of diversity than vascular plants, and uniform management practices and conservation measures may not be appropriate. On the other hand, significant correlations between the major plant groups have important implications not only for monitoring diversity but also for resolving problems in community structure, classification of vegetation types, ecosystem function, and the relative importance of micro- versus macro-environmental variables.

Differences between the biology of vascular plants and that of bryophytes and lichens suggest that patterns of diversity and response to environmental gradients among these groups could well be different. Bryophytes and lichens lack roots and draw most of their water and nutrients from the atmosphere; they have very limited control of the uptake and loss of water (Hale 1967; Scott 1994). Dispersal patterns are potentially different from those of vascular plants (with the exception of ferns) because bryophytes and lichens are spore dispersed and routinely reproduce vegetatively from very small fragments-even single cells in the case of bryophytes (Miles \& Longton 1992; Scott 1994). But these differences may be of little significance with respect to largescale factors, such as fire and moisture availability, because both vascular and nonvascular plants may be responding in similar ways to these environmental variables, resulting in their diversities being significantly correlated. The evidence so far is equivocal but suggests that the net effect may depend on the vegetation type.

Studies of the correlations between bryophytes or lichens and vascular plants have concentrated on boreal forests and montane areas of the northern hemisphere, where bryophytes and lichens often constitute a major portion of the species richness and biomass (Lee \& La Roi 1979; McCune and Antos 1981a; Alpert \& Oechel 1982; Bradfield \& Scagel 1984; Carleton 1990; Økland \& Eilertsen 1994; Rey Benayas 1995). In boreal forests of central Sweden, no relationship was found between bryophyte and vascular plant species richness (Söderström 1981). Slack (1977) describes bryophyte species richness and tree or shrub species richness as unrelated along an elevation gradient. A nation-wide study in Britain, however, described patterns of fern and liverwort species richness as very similar (Lawton et al. 1994).

Differences in rates of species turnover between bryophytes, lichens, and the vascular plant categories could indicate that different numbers of sites may be required for reservation. Bryophytes had a lower turnover along an elevation gradient than understory vascular plants in the Canadian Rocky Mountains, although turnovers along a moisture gradient are similar (Lee \& La Roi 1979). Two other studies in western Canada found that terrestrial bryophytes have a lower turnover than herb, shrub, or tree layers (Bradfield \& Scagel 1984; Rey Benayas 1995). Correlations between patterns of species turnover are strongest between adjacent strata, such as bryophyte and herb layers, although all correlations are weak. There are no estimates anywhere of the rate of lichen species turnover. A study of fir forests in the northern United States, however, examined layers consisting of a mixture of bryophytes and lichens (McCune \& Antos 1981b) and revealed that epiphytes (mostly lichens with some bryophytes) have a lower turnover than trees and shrubs; in contrast to the Canadian studies, terrestrial bryophytes were found to have a higher turnover than trees and shrubs.

In Australia only two studies have investigated correlations between the diversities of vascular plants, bryophytes, and lichens (Jarman \& Kantvilas 1994; Fensham \& Streimann 1997). Both found significant correlations. In Queensland dry rainforest, moss species richness can be predicted from vascular plant species richness (Fensham \& Streimann 1997). In Tasmanian rainforest, where bryophytes and lichens represented $89 \%$ of plant species richness, the classification of the sites was identical when vascular plants or bryophytes and lichens were used (Jarman \& Kantvilas 1994). 
Given the background literature, our study, which focused on dry habitats and was inclusive of bryophytes and lichens, is the first of its kind. In general, dry forests, where bryophytes and lichens are normally less abundant, have been neglected. We investigated whether the species richness and turnover of vascular plants-as opposed to total vascular plant cover (Pharo \& Beattie 1997) - predict the species richness and turnover of bryophytes and lichens, and we addressed three hypotheses: (1) The species richness of bryophytes and lichens is significantly correlated with the species richness of all vascular plants, overstory species only, understory species only, and ferns. (2) Bryophyte and lichen species turn over at the same rate and pattern as the four vascular plant categories. (3) The environmental variables that explain statistically significant variation in bryophyte and lichen species richness and turnover also explain significant variation in the species richness and turnover of the four vascular plant categories.

\section{Methods}

\section{Study Sites}

We sampled 35 sites, each $20 \times 50 \mathrm{~m}$, in coastal lowland forest located 70-140 km north of Sydney, New South Wales (NSW). The sites were simultaneously surveyed for vascular plants by State Forests of NSW in the course of a broad-scale environmental impact assessment (State Forests of New South Wales 1995). The sites ranged from open forest with a grassy understory to sheltered, wet sclerophyll forest with a rainforest understory. Four sites were adjacent to creeks and are referred to as riparian. Average daily maximum temperatures for the area ranged from $15^{\circ} \mathrm{C}$ in July to $27^{\circ} \mathrm{C}$ in January, and annual rainfall ranged from $1200 \mathrm{~mm}$ to $1400 \mathrm{~mm}$ (Forestry Commission of New South Wales 1984). Rainfall is seasonal, with more than twice as much rain falling in summer as in winter.

\section{Sampling}

We identified vascular plants, bryophytes, and lichens and estimated their abundance. We estimated vascular plant abundance in the $20 \times 50 \mathrm{~m}$ site using cover codes: <5\%, 6-25\%, 26-50\%, 51-75\%, >75\% (Binns 1996). Four categories of vascular plants were identified: (1) all vascular plants, (2) overstory species (diameter at breast height $[\mathrm{dbh}]>10 \mathrm{~cm})$, (3) understory species $(\mathrm{dbh}<10 \mathrm{~cm})$, and (4) ferns. The understory plant data set included ferns; but ferns were also analyzed separately because, like bryophytes and lichens, they are spore-dispersed.

Different substrates often support different assemblages of bryophytes and lichens (Brodo 1973; Söderström 1993). Five randomly located quadrats on each of five different substrates (ground, logs, rocks, tree trunks, and fallen branches) were sampled for bryophytes and lichens in the $20 \times 50 \mathrm{~m}$ site. Fallen branches probably include some canopy species, but the majority of the sampling was of species near ground level. A wire mesh quadrat $20 \times 20 \mathrm{~cm}$ was wrapped around fallen branches, logs, rocks, and bases of tree trunks. The relative abundance of each species was recorded as the number of times a species occurred directly beneath any one of the 100 intersections of the wire mesh. A pilot study showed that a $1 \times 1 \mathrm{~m}$ quadrat was necessary to sample the sparsely distributed bryophytes and lichens on the ground and fallen branches. Abundance was recorded in the same manner as for the other substrates. For our purposes, data from the 25 quadrats ( 5 substrates $\times 5$ quadrats per substrate) were pooled to give species abundance per $20 \times 50 \mathrm{~m}$ site.

Nomenclature followed that of Streimann and Curnow (1989) for mosses, Scott and Bradshaw (1986) for liverworts and hornworts, McCarthy (1991) for lichens, and Harden (1990-1993) for vascular plants.

\section{Environmental Variables}

Nine environmental variables were recorded at each site. The first four quantified disturbance: time since logging, time since last fire, intensity of logging, and intensity of the last fire. Information on logging and fire was obtained from management records and field estimation (Binns 1996). Time since logging ranged from 4 to 50 years. Eight unlogged sites were included. Time since fire ranged from 1 to 50 years. For one site there was no evidence or record of fire, so it was referred to as unburned. The unlogged and unburned sites were given the value of 80 years since logging or fire. Trials showed that values of 50,80 , or 100 years made no significant difference, except in one case that we mention in the results. No distinction was made between wildfire and planned burns. The intensity of the last fire and logging events was assessed as either light $(<30 \%$ canopy removal); moderate (30-60\% canopy removal); or severe (60-70\% canopy removal, rarely more) (D.B., personal observation).

The remaining five site factors were elevation, aspect, slope, topographic position, and vascular plant cover. Elevation ranged between 30 and $530 \mathrm{~m}$ above sea level. Aspect was coded as follows: 1, north; 2, northeast or northwest; 3, east or west; 4, southeast or southwest; 5 , south. This approach avoided the problem that north is both $0^{\circ}$ and $360^{\circ}$ if compass bearings are used and assumed that the greatest differences were between north and south (Söderström 1981). Slope was measured in degrees from the horizontal. Topographic position ranged from upper slopes-because there were no summit or ridge-top sites-to the sites beside creeks (1, upper slope; 2, mid-slope; 3, lower slope; 4, riparian; Binns 1996). 
Percent cover of vascular plants was calculated as follows: up to four vascular plant strata were identified (1-6 $\mathrm{m}, 6.1-20 \mathrm{~m}, 20.1-35 \mathrm{~m}$, over $35 \mathrm{~m}$ ), the percentage of the site covered by each stratum was estimated (0-100\%), and then the percent cover of all strata were summed (Binns 1996). Soil depth and soil type were also recorded but not included in the analysis because all sites were on deep, loamy soils.

\section{Data Analysis}

Regional species richness was defined as the number of species found in all 35 sites and local species richness ( $\alpha$-diversity) as the number of species present at a single site (Whittaker 1977). Variation in bryophyte and lichen species richness explained by vascular plant species richness and the environmental variables was determined by simple and multiple regression. Quadratic and cubic regressions were used to test for nonlinear relationships (SPSS, release 6.0 1993). Environmental variables were correlated by Pearson product-moment correlation to check for collinearity (Sokal \& Rohlf 1995).

Species turnover ( $\beta$-diversity) can be defined in the following overlapping senses: (1) turnover along gradients, (2) turnover through space, and (3) a measure of the difference between samples (Ricklefs \& Schluter 1993; Heywood 1995; Oksanen \& Tonteri 1995). We used species turnover in the second sense (turnover through space) because changes in species composition were measured between 35 sites in a region $70 \times 50$ $\mathrm{km}$. Species composition referred only to the suite of species present at a site, whereas species turnover quantified the change in species compositions between sites.

Although species turnover is an apparently simple concept, its multidimensional nature does not facilitate easy quantification. We used four different measures of species turnover to characterize changes. The first two measures are modifications of Whittaker's (1960) original beta, ( $S$ / $\alpha)-1$, where $S$ is the total number of species in the region, and $\alpha$ is the average species richness. In the first measure, Harrison et al. (1992) modified the original beta to range between 0 (complete similarity) and 100 (complete dissimilarity) and to take into account differences in the total number of sites $(N)$. Like Whittaker's original measure, beta-1 determines the relationship between average species richness and the total number of species in the region: $(S / \alpha-1) /(N-1) \times 100$. In the second measure, beta- 2 determines the relationship between maximum species richness and the total number of species in the region: $\left(S / \alpha_{\max }-1\right) /(N-1) \times 100$, where $\alpha_{\max }$ is the number of species at the most species-rich site (Wilson \& Shmida 1984; Harrison et al. 1992). The higher the species turnover, the greater the difference between values of species richness and the total pool of species in the region. If species-poor sites are subsets of species-rich sites, beta- 2 will be low because the highest value of spe- cies richness will approach regional species richness. Beta-1, however, will be higher than beta-2 because average species richness will still be much lower than regional species richness. Third, the gradient length of the first axis of detrended correspondence analysis is a measure of the mean standard deviation of species turnover and has all the advantages of ordination as a tool for summarizing data (Eilertsen et al. 1990). We used binary data rather than abundance data because it has been demonstrated that different abundance scales can influence the length of the gradient (Eilertsen et al. 1990). The fourth measure is an extension of mean dissimilarity among samples (often using Jaccard's or Sørensen's coefficient). The number of clusters formed at three arbitrary levels of Bray-Curtis dissimilarity, 0.8, 0.7, and 0.6, were compared between groups (using unweighted pair group metric averaging [UPGMA], $\beta=0$; Pattern Analysis Package [PATN]; Belbin 1991 $a, 1991 b)$. If sites had few species in common, species turnover was high and many clusters were formed. In contrast to gradient length, this multivariate measure uses all gradients rather than just the first.

Patterns of species turnover were investigated in three ways. First, we correlated all six similarity matrices (bryophytes, lichens, all vascular plants, understory, overstory, ferns) with one another using Pearson's product-moment correlation coefficient $(r)$ (PATN; Belbin 1991a, 1991b). Mantel tests were then used on each pair of matrices to estimate their degree of resemblance (Sokal \& Rohlf 1995). Second, the Pearson's productmoment correlations produced by the first method were themselves ordinated to show the compositional similarity of all major categories so that those close together on the ordination diagram had a similar pattern of species turnover between sites (Digby \& Kempton 1987; Oliver et al. 1998). Third, clustered results were superimposed on ordination diagrams to visually compare site placement for all six groups. Visual comparison allows sites that are highly similar or dissimilar (i.e., close or distant on ordination diagrams) to be identified easily and compared for each taxa. To simplify interpretation of the ordination diagrams, sites with similar bryophyte or lichen species composition were given the same symbol or number. These symbols were then used to label the fern, overstory, understory, and all vascular plant ordination diagrams. Sites were clustered by UPGMA and ordinated by hybrid multidimensional scaling (using DECODA, Minchin $1991 ; 25$ random starts, cut value $=0.8$, otherwise default parameters used; Faith et al. 1987).

Environmental variables were related to the pattern of species composition or turnover by canonical correspondence analysis (CCA; ter Braak \& Prentice 1988; Jongman et al. 1995; CANOCO, version 3.10, ter Braak 1991; all options followed the default settings unless otherwise stated). The CCA can partition variation explained by each variable and construct a model of significant variables (forward selection of variables option). 
Once a variable is added to the model, the fit and significance of the remaining variables is reassessed. The significance of the environmental variables was tested by a Monte Carlo approach with 999 permutations $(\alpha=$ 0.05; Sokal \& Rohlf 1995).

\section{Results}

\section{Regional Diversity and Species Richness}

Approximately three times as many vascular plants as bryophytes and lichens were found in the 35 sites: 477 vascular plant species compared to 146 bryophytes and lichens. The ratio of bryophyte and lichen species to vascular plant species at individual sites ranged from 1:1.3 in one of the riparian sites to $1: 5.4$ in one of the drier, recently burned sites. Most of the vascular plant richness was in the understory; only 45 of the 477 species belonged to the overstory. Thirty-nine species of fern were found.

The average species richness of vascular plants at a site was $67.4 \pm 2.2(\mathrm{SE})$, with an average of $60.6 \pm 2.2$ understory species, $4.2 \pm 0.2$ overstory species, and $4.8 \pm 0.7$ ferns. Average bryophyte and lichen species richness was $9.2 \pm 1.0$ and $15.5 \pm 1.0$, respectively.

Correlations among the categories showed that fern species richness was an excellent predictor of bryophyte species richness (Fig. 1). Lichen species richness was also highly correlated with fern species richness: sites rich in fern species (and bryophytes) were poor in lichen species. The only other significant correlation was between overstory and bryophyte species richness $\left(r^{2}=0.16, p=0.014\right)$. The species richness values for understory and all vascular plants varied little over the 35 sites and, as a consequence, were poor predictors of bryophyte and lichen species richness.

Time since fire, topographic position, and the cover of vascular plants explained significant variations in fern, bryophyte, and lichen species richness (Table 1). Fire intensity explained little variation in bryophyte and lichen species richness, but it was important for ferns because fewer fern species were present following more intense fires. None of the nine environmental variables explained significant variation in the species richness of all vascular plants, the understory, or the overstory. But time since logging came close to significance for understory species richness $\left(r^{2}=0.11, p=0.051\right)$. Understory species richness was highest in the most recently logged sites (about 80 species per site) and then decreased to the least-rich sites at 35 and 40 years (about 50 species per site). The eight unlogged sites (nominally for 80 years) were slightly richer on average than the least-rich sites. If the unlogged sites are given a value of 50 years instead of 80 , the correlation was significant at $\alpha=0.5\left(r^{2}=0.15, p=0.02\right)$. Fitting a quadratic regression, with the unlogged sites given values of 80 years
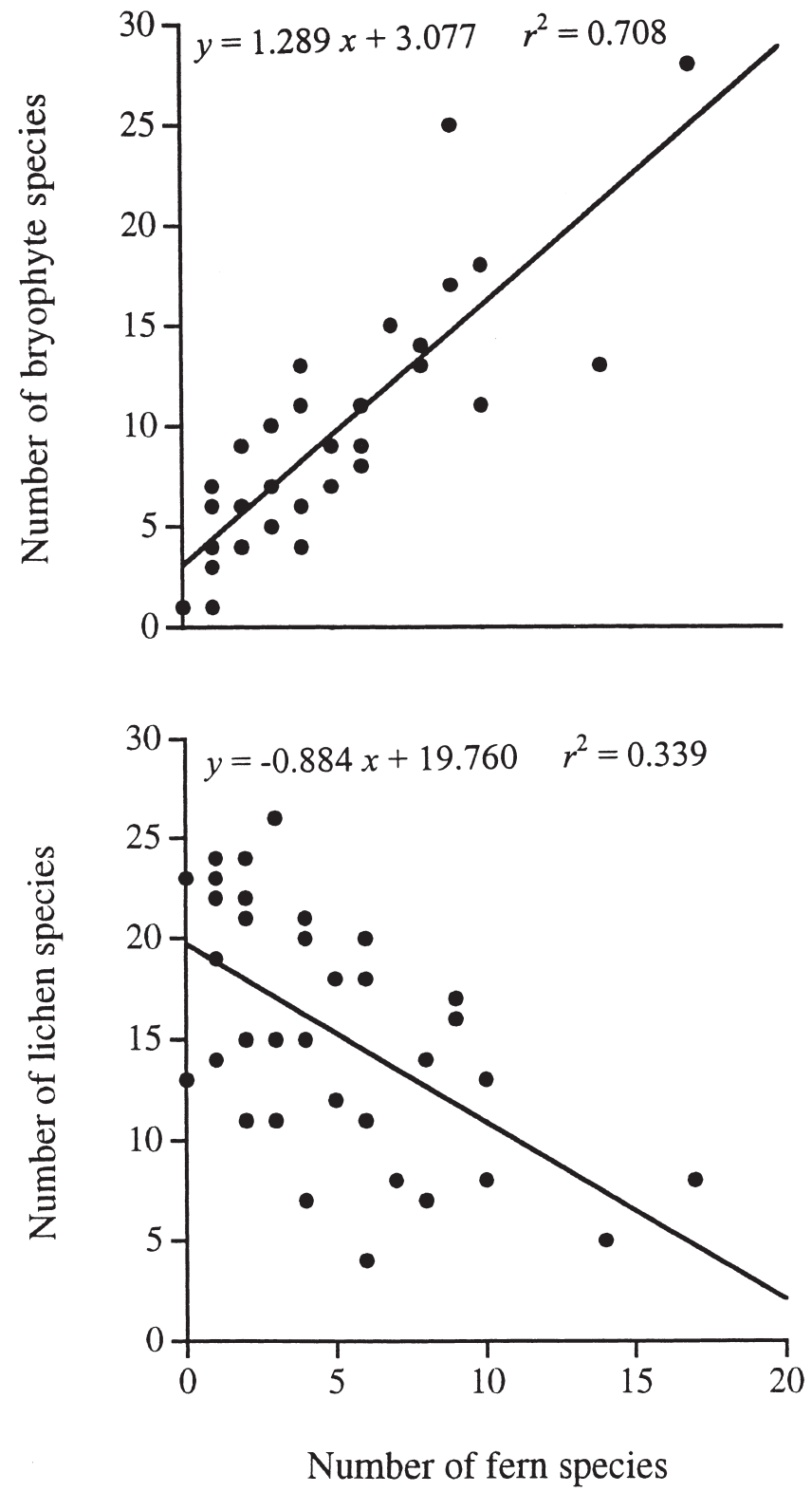

Figure 1. Regressions of fern and bryophyte species richness and fern and lichen species richness.

since logging, also yielded a significant result $\left(r^{2}=0.21\right.$, $p=0.02$ ). These alternative analyses, however, did little to change the strength of relationship, which was low. No significant nonlinear relationships were found between the species richness of either vascular plants or overstory species only (or bryophytes or lichens) and any of the environmental variables.

\section{Species Turnover}

\section{RATE OF SPECIES TURNOVER}

The rate of lichen species turnover was lower than the turnover of all four categories of vascular plants, with the 
Table 1. Regression $\left(r^{2}\right)$ of the species richness of the four categories of vascular plants with nine environmental variables. ${ }^{a}$

\begin{tabular}{|c|c|c|c|c|c|c|}
\hline Environmental variable & Bryopbyte & Licben & Fern & Overstory & Understory & All vascular plants \\
\hline Vascular plant cover & $+0.30^{b}$ & $-0.40^{b}$ & $+0.42^{b}$ & 0.08 & 0.00 & 0.00 \\
\hline Topographic position & $+0.51^{b}$ & $-0.17^{c}$ & $+0.47^{b}$ & 0.10 & 0.05 & 0.07 \\
\hline Time since fire & $+0.56^{b}$ & $-0.11^{c}$ & $+0.24^{d}$ & 0.05 & 0.02 & 0.03 \\
\hline Fire intensity & 0.05 & 0.00 & $-0.15^{c}$ & 0.03 & 0.06 & 0.05 \\
\hline Time since logging & 0.04 & 0.01 & 0.04 & 0.06 & 0.11 & 0.09 \\
\hline Logging intensity & 0.02 & 0.06 & 0.01 & 0.01 & 0.01 & 0.01 \\
\hline Elevation & 0.04 & 0.00 & 0.07 & 0.07 & 0.04 & 0.06 \\
\hline Aspect & 0.04 & 0.05 & 0.01 & 0.01 & 0.00 & 0.00 \\
\hline Slope & 0.03 & 0.02 & 0.08 & 0.00 & 0.08 & 0.07 \\
\hline
\end{tabular}

${ }^{a}$ Minus and plus signs indicate the direction of the effect.

${ }^{b} \mathrm{p}<0.001$.

$c_{\mathrm{p}}<0.05$

${ }^{d} \mathrm{p}<0.01$.

single exception that beta-2 found that lichen species turnover was slightly higher than fern species turnover (Table 2). This was because fern species composition was strongly "nested" within one riparian site that was particularly species-rich. In other words, the species found at sites with lower species richness were subsets of the species found at the richest site. Bryophytes were also strongly nested; two sites were particularly species-rich giving a large difference between the two beta indices. Beta-2, the index of maximum species richness, showed that bryophyte species richness was lower than overstory, understory, and all vascular plant species richness.

Overstory species had the greatest spread along the first detrended correspondence analysis (DCA) axis and therefore the greatest dissimilarity in species composition between sites (Table 2). Lichens had the least spread, and bryophytes, ferns, understory species, and all vascular plants species had similar values. The inclusion of abundance data and consideration of all potential gradients simultaneously in the UPGMA analyses yielded quite different results. The number of clusters at the 0.6 level of dissimilarity rose in the order lichens $>$ ferns $>$ bryophytes $>$ overstory $>$ understory $=$ all vascular plants. Comparison of the rate of understory and vascular plant species turnover with that of bryophytes and lichens was not straightforward because the turnover of the understory and all vascular plant species was low at the 0.8 level of dissimilarity but highest of all categories at the 0.6 level of species turnover. Turnover may have been low at the 0.8 level because of the large number of understory species common to many of the 35 sites. Many pairwise site dissimilarities for the understory were between 0.7 and 0.6, so many clusters were formed at the 0.6 level.

\section{PATTERN OF SPECIES TURNOVER}

By correlating all six similarity matrices, we found that both bryophyte and lichen species turnover were highly significantly correlated with the species turnover of all four vascular plant categories. Most of the correlations were reasonably weak, however, (bryophyte-fern, $r=$ 0.21 ; bryophyte-overstory, $r=0.23$; bryophyte-understory, $r=0.45$; bryophyte-all vascular plants, $r=0.44$; lichen-fern, $r=0.22$; lichen-overstory, $r=0.17$; lichenunderstory, $r=34$; lichen-all vascular plants, $r=0.35$; all combinations, $p<0.000$ ). The proximity and therefore similarity in turnover of the understory and all vascular plants occurred because the understory contained the most vascular plant diversity (Fig. 2). The understory and all vascular plants were the strongest predictors of

Table 2. Measures of species turnover for six categories of plants and lichens: DCA gradient length and number of unweighted pair group metric averaging (UPGMA) clusters formed at three levels of dissimilarity.

\begin{tabular}{lcccccr} 
& Bryophyte & Lichen & Fern & Overstory & Understory & All vascular plants \\
\hline Beta-1 $^{a}$ & 21.7 & 10.2 & 20.3 & 28.6 & 18.0 & 17.9 \\
Beta-2 $^{b}$ & 5.1 & 4.7 & 3.6 & 16.0 & 4.4 & 12.6 \\
DCA gradient length & 4.8 & 2.4 & 5.1 & 6.8 & & 4.5 \\
Number of clusters & & & & 6 & 2 & 8 \\
0.8 & 10 & 2 & 8 & 11 & 21 & 8 \\
0.7 & 15 & 7 & 13 & 17 & 21 \\
0.6 & 6 & & & & & 2 \\
\hline
\end{tabular}

${ }^{a}(\mathrm{~S} / \alpha-1) /(\mathrm{N}-1) \times 100$.

${ }^{b}\left(\mathrm{~S} / \alpha_{\max }-1\right) /(\mathrm{N}-1) \times 100$ 


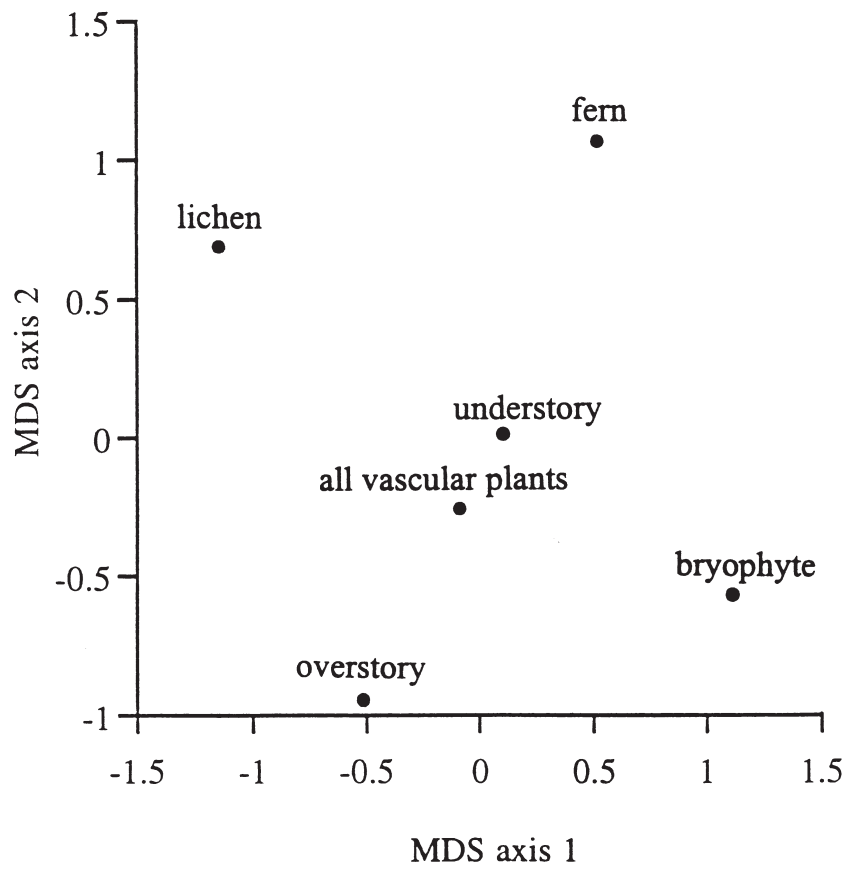

Figure 2. Ordination diagram showing bryophytes, lichens, and the four vascular plant categories (hybrid multidimensional scaling, with 25 random starts, cut value $=0.8$, otherwise default parameters used). Each of the six dissimilarities matrices were correlated to the other five, and the resulting Pearson $\mathrm{r}$ values were re-ordinated. The closer the groups in ordination space, the more similar the pattern of species composition or turnover.

the pattern of bryophyte and lichen species turnover. But despite statistically significant correlations, none of the relationships was particularly strong.

Compressing species turnover into rates and correlations does not indicate where the dissimilarities are greatest or why this pattern of species turnover correlates for some categories and not others. For bryophytes and the four vascular plant categories, the coincidence in pattern of species turnover was strongest between bryophytes and the understory (and therefore all vascular plants) and stronger for bryophytes than lichens (Fig. 3). Despite the correlations not being particularly strong, there is considerable cohesiveness between bryophytes and other taxa for the wet sclerophyll sites (coded 3 and R; Fig. 3). Even for lichens, many of the dry sclerophyll (coded 1) and the wet sclerophyll (coded 3) sites stayed close, revealing similar lichen and understory species compositions (Fig. 4).

\section{ENVIRONMENTAL VARIABLES}

Time since fire was the strongest predictor of species turnover in all six plant categories (Table 3). The two variables strongly correlated with time since fire (i.e., vascular plant cover and topographic position [time since fire - vascular plant cover: $r=0.47, p=0.004$; time since fire - topographic position: $r=0.61, p<$ $0.001])$ explained not only significant bryophyte and lichen species turnover but also significant species turnover in all four vascular plant categories. Although the two logging variables did not explain significant bryophyte and lichen species turnover, time since logging explained significant understory species turnover and came close to explaining significant fern species turnover (percent explained $=5.1, p=0.052$ ). Logging intensity was among the seven variables that accounted for significant fern species turnover.

Overlap in variation explained by the environmental variables was taken into account by removing variation due to the strongest variable and then reassessing the rest (Table 4). The three strongest variables in the models were the same, except for ferns, which had slope as the third variable instead of elevation. Time since logging was included in the understory and all vascular plant models.

\section{Discussion}

Our data reveal that it may be unwise to treat as a single group the various taxonomic and functional categories often lumped together as "plants." Bryophytes and lichens should not be ignored, however, because they were a substantial component of biodiversity in our sites, with a regional richness of approximately one-third that of vascular plants. One category of vascular plants, ferns, showed potential as a surrogate for bryophyte species richness. Ferns were the only significant vascular plant group to correlate significantly with lichen in species richness. In common with Söderström (1981) and in contrast with an Australian study (Fensham \& Streimann 1997), we found no correlation between the species richness of bryophytes and that of all vascular plants. Our results also contrast with Slack's qualitative results (1977) because we found a significant correlation between bryophyte and overstory species richness. Our results may be dependent on the vegetation types included, in particular the riparian sites that had high species richness of both bryophytes and trees.

Bryophyte and fern species richness were positively correlated, whereas fern and lichen richness were negatively correlated (Fig. 1). Both bryophytes and ferns are dependent on a film of water on the under-surface of the gametophyte and reproduce sexually only in mesic environments. Ferns and bryophytes not only have the same requirements for reproduction, but the gametophyte stage of the fern life cycle looks very similar to a thallose liverwort and is often mistaken for one. Little is understood of lichen requirements for sexual reproduction, but they have no known dependence on free water (Hale 1967). Their apparent independence from water 

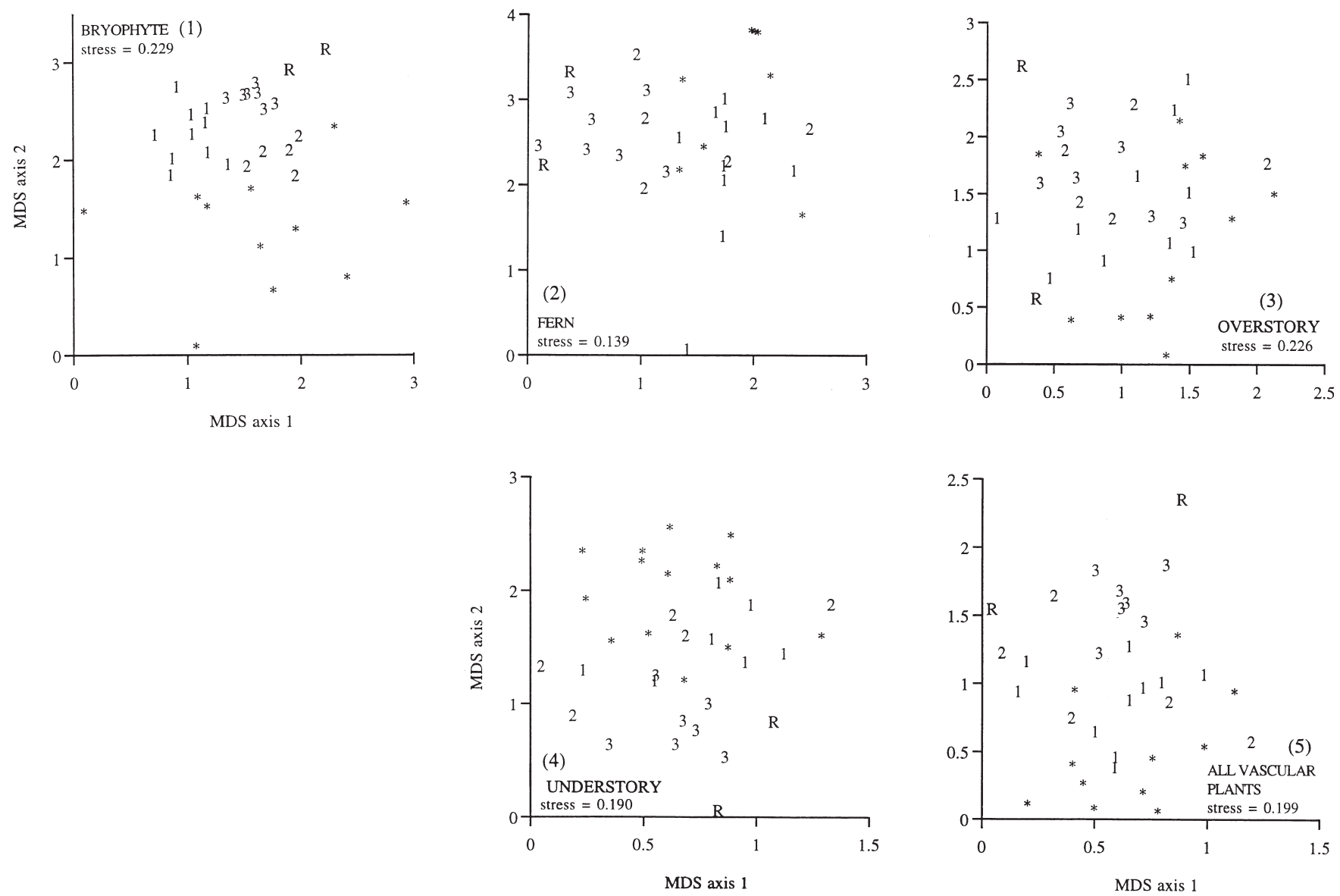

Figure 3. Sites coded according to bryophyte composition (clustering results) plotted on independent ordination diagrams for bryophytes (1), ferns (2), overstory (3), understory (4), and all vascular plants (5). An asterisk indicates outlying sites (dissimilarities greater than 0.6); $R$ indicates outlying riparian sites (two sites with similar species compositions but outliers compared to the rest of the sites); 1,2,3 clusters formed at the 0.6 level of dissimilarity. The stress value measures the mismatch between the dissimilarities calculated from the species data against the distances between sites on the ordination diagram (Belbin 1991b:130).

contrasts with bryophytes and ferns and may explain the negative correlations.

We found that the rate of species turnover of bryophytes and the vascular plant categories was similar. Bryophyte species turnover was slightly higher or lower, depending on the emphasis of the measure and was most closely paralleled by fern species turnover. The only other study that recognized different categories of vascular plants revealed that the terrestrial bryophyte layer has a similar but slightly higher turnover than shrubs (McCune \& Antos 1981b). The bryophytes in these North American forests, however, have a higher turnover than the trees, a result that contrasts with our findings. The reason for the difference may be the relatively low number of tree species and the low species turnover found in North American forests. Another possibility is that our sites have less of a range in stand age. Lichens and bryophytes are often more dynamic than the tree layer, resulting in higher turnover for stands with larger age ranges.

In addition to this North American study, three other studies compare the rate of turnover of bryophytes with vascular plants as a group (Lee \& La Roi 1979; Bradfield \& Scagel 1984; Rey Benayas 1995). These studies also found the rate of species turnover of bryophytes is lower than that of all vascular plants. Rates of turnover depend on the range of habitats included in the study. Many of the bryophytes and lichens typical of drier habitats are widely distributed, and low species turnover may be expected between dry habitats separated by long distances (Longton 1988). The rate of species turnover among lichen was the lowest of all, agreeing with the only North American study of similar scope (McCune \& Antos 1981b).

Patterns of bryophyte and lichen species turnover were highly significantly correlated with the pattern of 

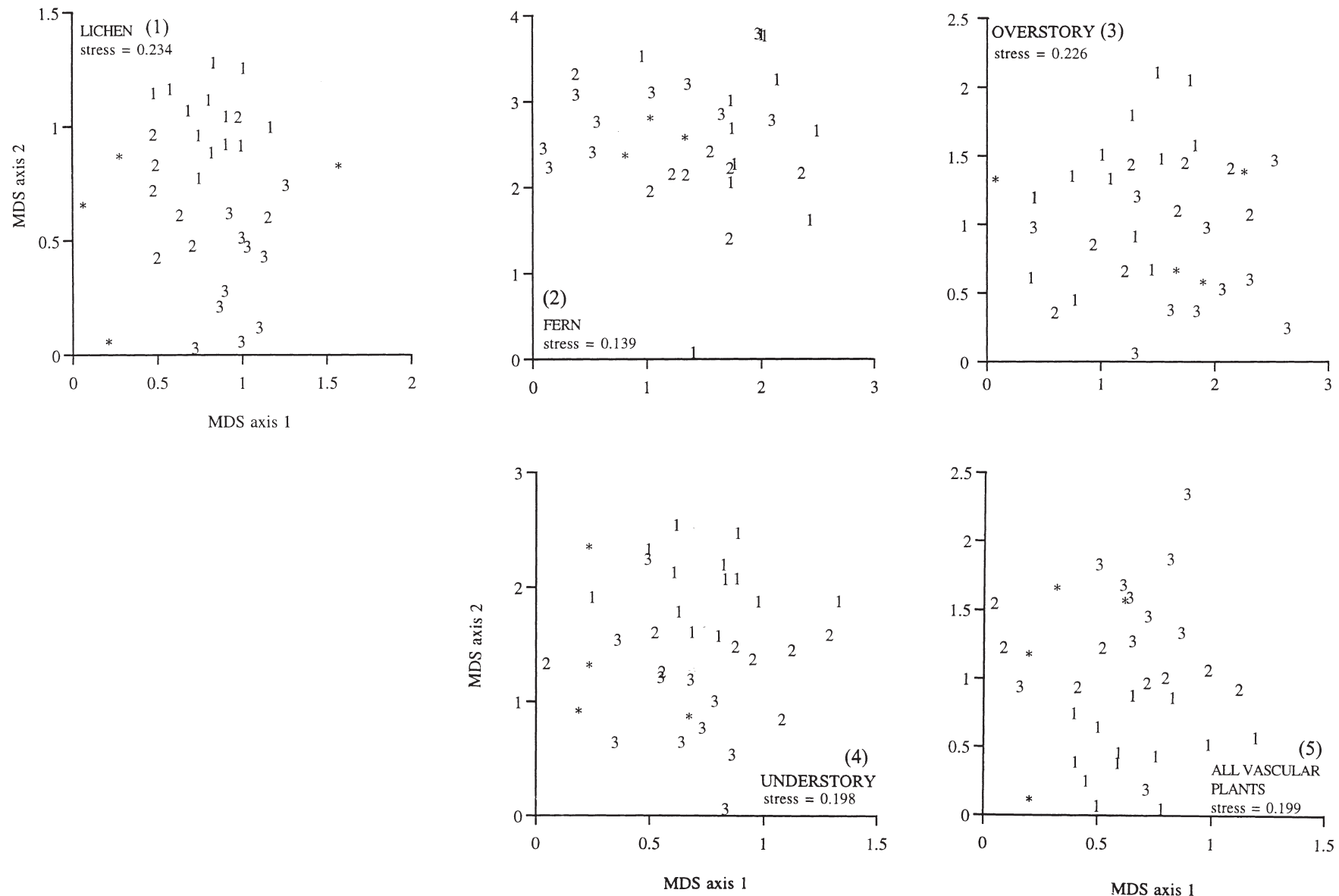

Figure 4. Sites with similar lichen compositions (clustering results) plotted on independent ordination diagrams for bryophytes (1), ferns (2), overstory (3), understory (4), and all vascular plants (5). An asterisk indicates outlying sites (dissimilarities greater than 0.5); 1,2,3 clusters formed at the 0.5 level of dissimilarity.

species turnover of each of the four vascular plant categories. The strongest correlations were with the understory and all vascular plant species. But even the pattern of understory species failed to account for most of bryophyte and lichen species turnover. Correlations ap- peared strongest in wet sclerophyll sites, where sites with similar understory compositions could be expected to have similar bryophyte and lichen compositions. This finding is supported by the results of the Tasmanian rainforest study in which the vascular plant and the bryo-

Table 3. A comparison of the amount of variation in bryophyte, lichen, and vascular plant species turnover explained by nine environmental variables.

\begin{tabular}{|c|c|c|c|c|c|c|}
\hline Vascular plant cover & $6.0^{a}$ & $4.8^{b}$ & $10.4^{a}$ & $5.8^{a}$ & $6.1^{a}$ & $6.3^{a}$ \\
\hline Elevation & 3.6 & 4.0 & 3.8 & $4.1^{c}$ & $4.1^{b}$ & $4.3^{b}$ \\
\hline Aspect & 3.4 & 3.1 & $5.3^{c}$ & 3.0 & 2.7 & 2.7 \\
\hline Slope & 3.4 & 3.5 & $7.0^{b}$ & $4.9^{b}$ & 3.2 & 3.3 \\
\hline Fire intensity & 2.1 & 2.6 & $7.2^{b}$ & 3.6 & 3.2 & 3.2 \\
\hline
\end{tabular}

${ }^{a} \mathrm{p}<0.001$.

${ }^{b} \mathrm{p}<0.01$

${ }^{c} \mathrm{p}<0.05$ 
Table 4. A comparison of the models of the best environmental variables for bryophytes and lichens and four vascular plant categories.

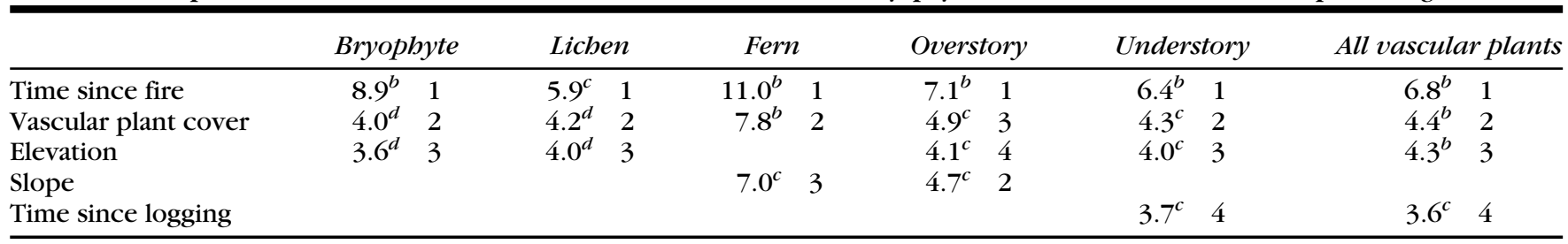

${ }^{a}$ Percent variation (left) is explained by the variable calculated by dividing the amount explained by each variable (forward selection of variables option, CCA) by the total variance in the species data. The rank of the variable (right) explains variation in the species data.

${ }^{b} \mathrm{p}<0.001$.

${ }^{c} \mathrm{p}<0.01$

$d_{\mathrm{p}}<0.05$

phyte and lichen classifications were obviously similar, even though they were not tested for significance (Jarman \& Kantvilas 1994).

Despite differences in dispersal mode, requirements for sexual reproduction, vegetative reproduction abilities, and water relations, the same major macroenvironmental variables were important in determining the patterns of diversity of all vascular plant categories and bryophytes and lichens. The species richness of bryophytes, lichens, and ferns all varied significantly with time since fire and with its two collinear variables, topographic position and vascular plant cover. The effect of time since fire on species richness of vascular plants has been the subject of a large body of literature (Whelan 1995), but its effect on bryophytes and lichens is much less well known. All fires appear to have been lethal for bryophytes and lichens no matter what the intensity. Fern species richness was also significantly correlated with fire intensity; however, unburned or lightly burned sites had more fern species than sites that experienced a severe burn. Unlike bryophytes and lichens, most ferns have mechanisms to protect them against total destruction from fire, such as underground rhizomes (Fox 1988).

The absence of significant variation in vascular plant species composition may be due to the rarity of severe fires in the region. These forests are managed for wood production and are control-burned to reduce the risk of very hot fires that kill trees. Mosaics of fires in space, time, and intensity should promote the maintenance of total plant and lichen diversity.

Logging appears to differentially affect the diversity of the vascular plant categories. The species turnover of all understory vascular plants was significant with time since logging, and fern species turnover was affected by logging intensity and, to a small extent, by time since logging. Again, a mosaic of different times since logging and logging intensities would appear to be important for maintaining regional diversity with some areas kept free of disturbance. The nature of the changes to the understory needs further analysis.

Our study, the first to compare bryophyte, lichen, and vascular plant regional species richness in the drier forests of mainland Australia, shows that bryophytes and li- chens represent a large portion of the total plant richness of the Morisset Forestry District. Fire and other variables related to moisture availability were important in determining the diversity of all four categories of vascular plants and of bryophytes and lichens. Although correlations were not strong enough for us to advise that bryophyte and lichen surveys are unnecessary, these parallels may provide a way for forestry agencies to target potentially diverse areas for these organisms without having to conduct an exhaustive survey.

\section{Acknowledgments}

We thank I. Oliver, J. B. Wilson, B. McCune, and L. Söderström for valuable discussion and comments on the manuscript. This research was supported in part by an Australian Postgraduate Research Award (to E.J.P.). This paper is submission number 266 of the Key Centre of Biodiversity and Bioresources, Macquarie University.

\section{Literature Cited}

Alpert, P., and W. C. Oechel. 1982. Bryophyte vegetation and ecology along a topographic gradient in montane tundra in Alaska. Holarctic Ecology 5:99-108.

Belbin, L. 1991a. PATN: pattern analysis package. User's guide. Division of Wildlife and Ecology, Commenwealth Scientific, Industrial, and Research Organization, Canberra, Australia.

Belbin, L. 1991b. PATN: pattern analysis package. Technical reference manual. Division of Wildlife and Ecology, Commenwealth Scientific, Industrial, and Research Organization, Canberra, Australia.

Binns, D. L. 1996. Flora survey, Morisett Forestry District, Central Region, New South Wales. Morisset Forestry District EIS support document 3. Research Division, State Forests of New South Wales, Sydney.

Bradfield, G. E., and A. Scagel. 1984. Correlations among vegetation strata and environmental variables in subalpine spruce-fir forests, southeastern British Colombia. Vegetatio 55:105-114.

Brodo, I. M. 1973. Substrate ecology. Pages 401-441 in V. Ahmadjian and M. E. Hale, editors. The lichens. Academic Press, London.

Carleton, T. J. 1990. Variation in terricolous bryophyte and macrolichen vegetation along primary gradients in Canadian boreal forests. Journal of Vegetation Science 1:585-594.

Digby, P. G. N., and R. A. Kempton. 1987. Multivariate analysis of ecological communities. Chapman \& Hall, London.

Eilertsen, O., R. H. Økland, T. Økland, and O. Pedersen. 1990. Data ma- 
nipulation and gradient length estimation in DCA ordination. Journal of Vegetation Science 1:261-270.

Faith, D. P., and P. A. Walker. 1996. How do indicator groups provide information about the relative biodiversity of different sets of areas? On hotspots, complementarity and pattern-based approaches. Biodiversity Letters 3:18-25.

Faith, D. P., P. R. Minchin, and L. Belbin. 1987. Compositional dissimilarity as a robust measure of ecological distance. Vegetatio 69:57-68.

Fensham, R. J., and H. Streimann. 1997. Broad landscape relations of the moss flora from inland dry rainforest in north Queensland, Australia. The Bryologist 100:56-64.

Forestry Commission of New South Wales. 1984. Management plan for Wyong Management Area. Forestry Commission of New South Wales, Pennant Hills, Sydney.

Fox, M. D. 1988. Understorey changes following fire at Myall Lakes, New South Wales. Cunninghamia 2:85-95.

Hale, M. E. 1967. The biology of lichens. Edward Arnold Ltd., London.

Harden, G. J. 1990-1993. Flora of New South Wales. Volumes 1-4. New South Wales University Press, Sydney.

Harrison, S., S. J. Ross, and J. H. Lawton. 1992. Beta diversity on geographic gradients in Britain. Journal of Animal Ecology 61:151-158.

Heywood, V. H. 1995. Global biodiversity assessment. Cambridge University Press, Cambridge, United Kingdom.

Jarman, S. J., and G. Kantvilas. 1994. Lichens and bryophytes of the Tasmanian World Heritage Area. II. Three forest sites at Pelion Plains. Tasforests 6:103-120.

Jongman, R. H. G., C. J. F. ter Braak, and O. F. R. Van Tongeren. 1995. Data analysis in community and landscape ecology. 2nd edition. Cambridge University Press, Cambridge, United Kingdom.

Lawton, J. H., J. R. Prendergast, and B. C. Eversham. 1994. The numbers and spatial distribution of species: analyses of British data. Pages $177-195$ in P. L. Forey, C. J. Humphries, and R. I. VaneWright, editors. Systematics and conservation evaluation. Clarendon Press, Oxford, United Kingdom.

Lee, T. D., and G. H. La Roi. 1979. Bryophyte and understorey vascular plant beta diversity in relation to moisture and elevation gradients. Vegetatio 40:29-38.

Longton, R. E. 1988. Life-history strategies among bryophytes of arid regions. Journal of the Hattori Botanical Laboratory 64:15-28.

McCarthy, P. M. 1991. Checklist of Australian lichens. National Herbarium of Victoria, Melbourne, Australia

McCune, B., and J. A. Antos. 1981a. Diversity relationships of forest layers in the Swan Valley, Montana. Bulletin of the Torrey Botanical Club 108:354-361.

McCune, B., and J. A. Antos. 1981b. Correlations between forest layers in the Swan Valley, Montana. Ecology 62:1196-1204.

Miles, C. J., and R. E. Longton. 1992. Deposition of moss spores in relation to distance from parent gametophytes. Journal of Bryology 17: 355-368.

Minchin, P. R. 1991. DECODA: database for ecological community data. Australian National University, Canberra, Australia.

Noss, R. F. 1990. Indicators for monitoring biodiversity: a hierarchical approach. Conservation Biology 4:355-364.

Økland, R. H., and O. Eilertsen. 1994. Canonical correspondence analysis with variation partitioning: some comments and an application. Journal of Vegetation Science 5:117-126.
Oksanen, J., and T. Tonteri. 1995. Rate of compositional turnover along gradients and total gradient length. Journal of Vegetation Science 6:815-824.

Oliver, I., A. J. Beattie, and A. York. 1998. Spatial fidelity of plant, vertebrate and invertebrate assemblages in multiple-use forest in eastern Australia. Conservation Biology 12:822-835.

Pharo, E. J., and A. J. Beattie. 1997. Bryophyte and lichen diversity: a comparative study. Australian Journal of Ecology 22:151-162.

Resource Assessment Commission. 1993. The use of surrogate measurements for determining patterns of species distribution and abundance. Research paper 8. Australian Government Press, Canberra, Australia

Rey Benayas, J. M. 1995. Patterns of diversity in the strata of boreal montane forest in British Columbia. Journal of Vegetation Science 6:95-98.

Ricklefs, R. E., and D. Schluter. 1993. Species diversity in ecological communities: historical and geographical perspectives. University of Chicago Press, Chicago.

Scott, G. A. M. 1994. Elementary reflections on the biology of bryophytes. The Victorian Naturalist 111:112-115.

Scott, G. A. M., and J. A. Bradshaw. 1986. Australian liverworts (Hepaticae). Brunonia 8:1-171.

Slack, N. G. 1977. Species diversity and community structure in bryophytes: New York State studies. Bulletin of the New York State Museum 428:1-70.

Söderström, L. 1981. Distribution of bryophytes in spruce forests on hill slopes in central Sweden. Wahlenbergia 7:141-153.

Söderström, L. 1993. Substrate preference in some forest bryophytes: a quantitative study. Lindbergia. A Journal of Bryology 18:98-103.

Sokal, R. R., and F. J. Rohlf. 1995. Biometry: the principles and practice of statistics in biological research. W. H. Freeman and Company, New York.

State Forests of New South Wales. 1995. Morisset Forestry District environmental impact statement. State Forests of New South Wales, Pennant Hills, Sydney.

Stolgren, T. J., J. F. Quinn, M. Ruggiero, and G. Waggoner. 1995. Status of biotic inventories in US National Parks. Biological Conservation 71:97-106.

Streimann, H., and J. Curnow. 1989. Catalogue of mosses of Australia and its external territories. Australian flora and fauna series 10. Australian Government Publishing Service Press, Canberra.

ter Braak, C. J. F. 1991. CANOCO: a FORTRAN program for canonical community ordination. Microcomputer Power, Ithaca, New York.

ter Braak, C. J. F., and I. C. Prentice. 1988. A theory of gradient analysis. Advances in Ecological Research 18:271-317.

Tracy, C. R., and P. F. Brussard. 1994. Preserving biodiversity: species in landscapes. Ecological Applications 4:205-207.

Whelan, R. J. 1995. The ecology of fire. Cambridge University Press, Cambridge, United Kingdom.

Whittaker, R. H. 1960. Vegetation of the Siskiyou Mountains, Oregon and California. Ecological Monographs 30:279-338.

Whittaker, R. H. 1977. Evolution of species diversity in land communities. Evolutionary Biology 10:1-67.

Wilson, M. V., and A. Shmida. 1984. Measuring beta diversity with presence-absence data. Journal of Ecology 72:1055-1064. 